THONNEY, M.L., TOUCHBERRY, R.W., GOODRICH, R.D. \& MEISKE, J.C., 1976. Intraspecies relationship between fasting heat production and body weight: A re-evaluation of $\mathrm{W}^{0.75}$. J. Anim. Sci. 43, 692-704.

TURNER, H.C., 1959. Ratios as criteria for selection in animal or plant breeding, with particular reference to efficiency of food conversion in sheep. Aust. J. agric. Res. 10, 565-580.

WAGNER, W.R., BRINKS, J.S., URICK, J.J., PAHNISH, O.F. \& RICHARDSON, G.V., 1984. A comparison of crossbred and straightbred cow-calf pairs. II. Biological efficiency of the cowcalf unit. J. Anim. Sci. 58, 1160-1170.

\section{The use of acid detergent insoluble nitrogen to predict digestibility of rumen undegradable protein of heat processed plant proteins'}

\section{G.E. Schroeder ${ }^{\star}$, L.J. Erasmus, K-J. Leeuw and H.H. Meissner}

Animal Nutrition and Animal Products Institute, Private Bag X2, Irene, 1675 Republic of South Africa

Received 30 April 1995; accepted 31 May 1996

The usefulness of acid detergent insoluble nitrogen (ADIN) to predict digestibility of rumen undegradable protein (UDP-D) of heat processed and unprocessed plant proteins was investigated. A series of drum roasted protein sources, sunflower, cottonseed and soybean oilcake meals, in addition to whole soybeans, whole sunflowerseed, whole cottonseed and whole lupinseed, were evaluated in this study to test the relationship between ADIN (\% of total N) and UDP-D. Using ADIN as a screening parameter, five samples on average of each protein source together with the unprocessed control were selected for an in situ study using the mobile bag technique (MBT) to determine UDP-D. Digestibility of undegradable protein was not significantly decreased as a result of heat treatment, when ADIN values were below 12$15 \%$, but progressively decreased when ADIN was higher, suggesting substantial heat damage. Ruminal nitrogen digestibility also decreased $(p<0.05)$ with heat treatment. Digestibility of undegradable protein was predicted with a $r^{2}=$ 0.72 and error of estimate (Sy.x) of $4.78 \%$. The prediction equation $(p<0.001)$ of UDP-D $(\%)=91.9-0.025$ (ADIN, \% in $D M)^{2}$, could therefore be a satisfactory guideline for predicting UDP-D and heat damage of the above-mentioned heat processed and unprocessed plant protein sources.

Die doel van die studie was om die suurseep-onoplosbarestikstof- (ADIN) analise te gebruik om die verteerbaarheid van die nie-degradeerbare proteïen (UDP-V) van ' $n$ wye reeks hitte-geprosesseerde en ongeprosesseerde plantaardige proteienbronne te voorspel. Om die verwantskap tussen ADIN (\% van totale $N$ ) en UDP-V te evalueer, is sonneblomoliekoekmeel, katoensaad-oliekoekmeel, en soja-oliekoek meel sowel as heel sojabone, heel sonneblomsaad; heel katoensaad en heel lupiensaad dromgerooster. Resultate van ADIN-analise is gebruik om gemiddeld vyf hitte-geprosesseerde asook die ongeprosesseerde kontrole te selekteer vir ' $n$ in situ evaluasie deur die mobielesakkie-tegniek (MBT) te gebruik om UDP-V te bepaal. Verteerbaarheid van niedegradeerbare proteïen het nie betekenisvol verlaag as gevolg van hittebehandeling wanneer ADIN onder 12-15\% was nie, maar het progressief verlaag wanneer ADIN hoër was, wat aansienlike hittebeskadiging voorstel. Ruminalestikstofverteerbaarheid het ook verlaag $(p<0.05)$ met hitfebehandeling. Verteerbaarheid van nie-degra-deerbare proteïen is voorspel met ' $n r^{2}=0.72$ en beramingsfout (Sy.x) van $4.78 \%$. Die voorspellingsvergelyk-ing $(\rho<0.001)$ van UDP-V $(\%)=91.9-0.025$ (ADIN, \% in DM $)^{2}$, behoort 'n nuttige riglyn te wees om UDP-V en hitte-beskadiging van hitte-geprosesseerde en ongeprosesseerde plantproteïenbronne te voorspel.

Keywords: roasting, plant protein, undegradable protein, ADIN, dairy cows

*Author to whom correspondence should be addressed

'Research supported by the Protein Research Trust, P.O. Box 8783. Pretoria, 0001 South Africa

There has been much interest in using indices of heat damage to protein sources, such as laboratory tests or even visual appraisal, to determine the value of a protein source (Merchen, 1990). Moderate heating may enhance the value of many protein sources by decreasing degradability in the reticulo-rumen, while not affecting digestion in the small intestine (SI), whereas overheating may be detrimental. Acid detergent insoluble nitrogen (ADIN) has been known to indicate heat damaged proteins in forage (Yu, 1976; 1977; Van Soest \& Mason, 1991; Broderick et al., 1993; Yang et al., 1993; Boila \& Ingalls, 1994) and in plant proteins (Drackley \& Schingoethe, 1986; Pena et al., 1986; Faldet et al., 1991; 1992; Reddy et al., 1993). Nakamura et al., (1994) furthermore obtained a linear relationship $\left(r^{2}=0.66\right)$ between ADIN and true nitrogen digestibility, but non-forage sources such as corn dried distillers grain and milo dried distillers grain were included, and he concluded that ADIN was a weak indicator of heat damage. Owing to its correlation with heat damage, $\%$ ADIN may prove useful to predict digestibility of undegradable protein (UDP-D) in the SI and this study further investigates this possibility.

Seven plant protein sources, sunflower oilcake meal (SFOC), cottonseed oilcake meal (CSOC), soybean oilcake meal (SOC), whole soybeans (WSB), whole sunflowerseed (WSS), whole cottonseed (WCS) and whole lupinseed (WLS), were drum roasted using a 6 temperature $\times 5$ time interval factorial design as described by Schroeder et al. (1995). An electrically driven drum roaster (45 l) using a gas flame as energy source and rotating at $23 \mathrm{rpm}$ was used. The protein sources were processed from $110^{\circ} \mathrm{C}$ to $210^{\circ} \mathrm{C}$ with $20^{\circ} \mathrm{C}$ intervals and the time intervals were $10,30,60,90$ and $120 \mathrm{~min}$ per setting. The temperature of the product was measured inside the drum using an electronic thermometer. After roasting, the product was cooled by an electrically powered fan situated underneath the drum. All processed protein sources as well as the corresponding unprocessed controls were analysed for ADIN as described by Goering \& Van Soest (1970). Demjanec et al. (1995) indicated that a maximum amount of amino acids (AA) ultimately disappeared in the SI of sheep when SOC was heated to the point where 12 to $15 \%$ of total $\mathrm{N}$ was in the form of ADIN. Using this as a norm, between four and seven samples of each protein source varying in ADIN from below $12 \%$ ADIN to above $15 \%$ ADIN, together with the unprocessed control, were selected for the in situ study.

Three rumen and duodenally cannulated lactating dairy 
cows were used in this study. The cows received a $17 \% \mathrm{CP}$ total mixed diet ad lib, maintaining an intake of about $23 \mathrm{~kg}$ $\mathrm{DM} / \mathrm{d}$. The mobile bag technique (MBT) as described by Kirkpatrick \& Kennelly (1985) was used to determine UDPD. Six mobile bags per cow per sample were filled $(1 \mathrm{~g} ; 2$ $\mathrm{mm}$ ) using two additional blanks to correct for microbial contamination. All bags were firstly incubated in the rumen (16 h) inside a large net bag (Nalsen et al., 1987). Following incubation, three bags and one blank were washed (10 min; cold water, washing machine) and dried $\left(55^{\circ} \mathrm{C} / 48 \mathrm{~h}\right)$. The remaining three bags and one blank were incubated in a pep$\sin -\mathrm{HCl}$ solution $\left(39^{\circ} \mathrm{C} / 3 \mathrm{~h}\right)$. After digestion, these bags were kept on ice at $4^{\circ} \mathrm{C}$ and inserted randomly into the duodenum via the duodenal cannula at a rate of one bag per $20 \mathrm{~min}$. Upon recovery from the faeces the bags were kept on ice at $4^{\circ} \mathrm{C}$ until all bags were recovered whereafter they were washed and dried as described. Digestibility values obtained using the MBT can be considered as an estimate of true digestibility (de Boer, et al., 1987; Hvelplund et al., 1994). For N-analysis, Macro-Kjeldahl (A.O.A.C., 1984) was used. Linear and non-linear regression equations of ADIN on UDPD were tested for best fit (SAS, 1990).

The acid detergent insoluble nitrogen and digestibility of undegradable protein values of drum roasted and unprocessed plant protein sources are shown in Table 1. Digestibility of undegradable protein was non-significantly decreased up to $12-15 \%$ ADIN, but was significantly and progressively decreased above this level, suggesting substantial heat damage. The ruminal nitrogen digestibility values are also depicted in Table 1 showing a significant decrease with temperature and time, clearly indicating the effect of heat processing. Digestibility of undegradable protein was predicted best using a non-linear function with $r^{2}=0.72$ and error of estimate (Sy.x) of $4.78 \%$. The prediction equation ( $p<$ $0.001)$ of UDP-D $(\%)=91.9-0.025(\%$ ADIN of total N, \% in $\mathrm{DM})^{2}$, appears to be a satisfactory guideline to predict UDP-D across plant proteins (Figure 1.). If however, a specific protein source is investigated the prediction equation for that protein source as shown in Table 2, may be used.

The low $r^{2}$ value of 0.19 for WSB is inexplicible but could possibly be because only three processed samples were selected with no large variation in \% ADIN. Secondly, it has been suggested that ADIN is not considered to be a useful indicator of heat damage with whole soybeans (Satter et al., 1994). Recent digestibility studies in sheep using SOC, a byproduct of WSB, in a total mixed diet have shown that ADIN is not an adequate measure of indigestible $\mathrm{N}$ for high-protein supplements (Hussein et al., 1995). Their conclusion was that ADIN was highly digestible in the digestible tract. Similar studies would be needed for other high-protein supplements.

Figure 1 depicts both the UDP-D and ADIN values of the plant protein sources and the non-linear equation. Increases in ADIN resulted in non-significant decreases in UDP-D up to $12-15 \% \mathrm{ADIN}$, but above $12-15 \% \mathrm{ADIN}$, small increases

Table 1 ADIN and UDP-D' of drum processed and unprocessed plant protein sources

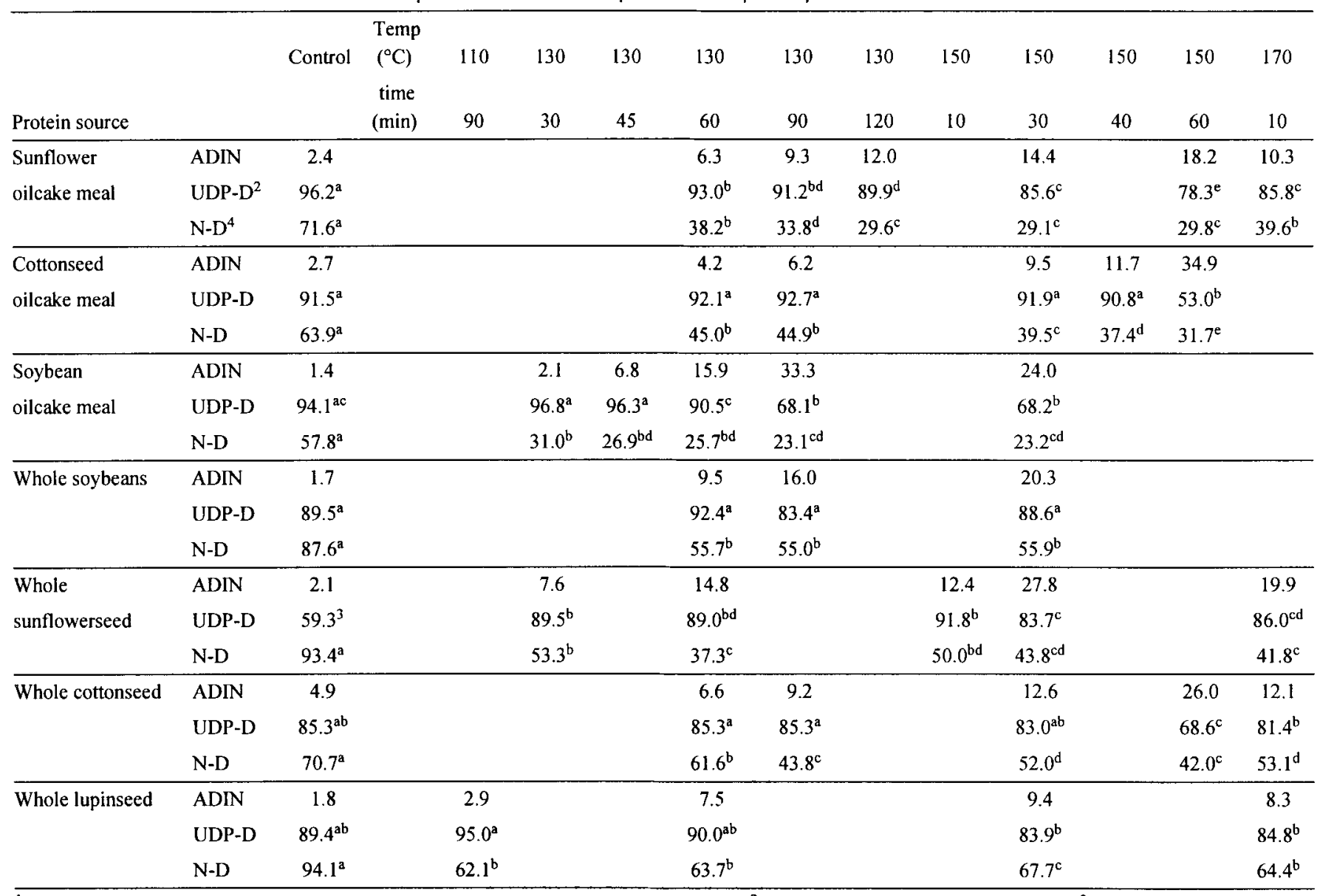

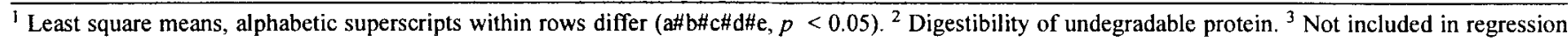
owing to exceptionally low value, possibly caused by the blocking of the pores in the mobile nylon bags. ${ }^{4}$ Nitrogen digestibility in the rumen. 


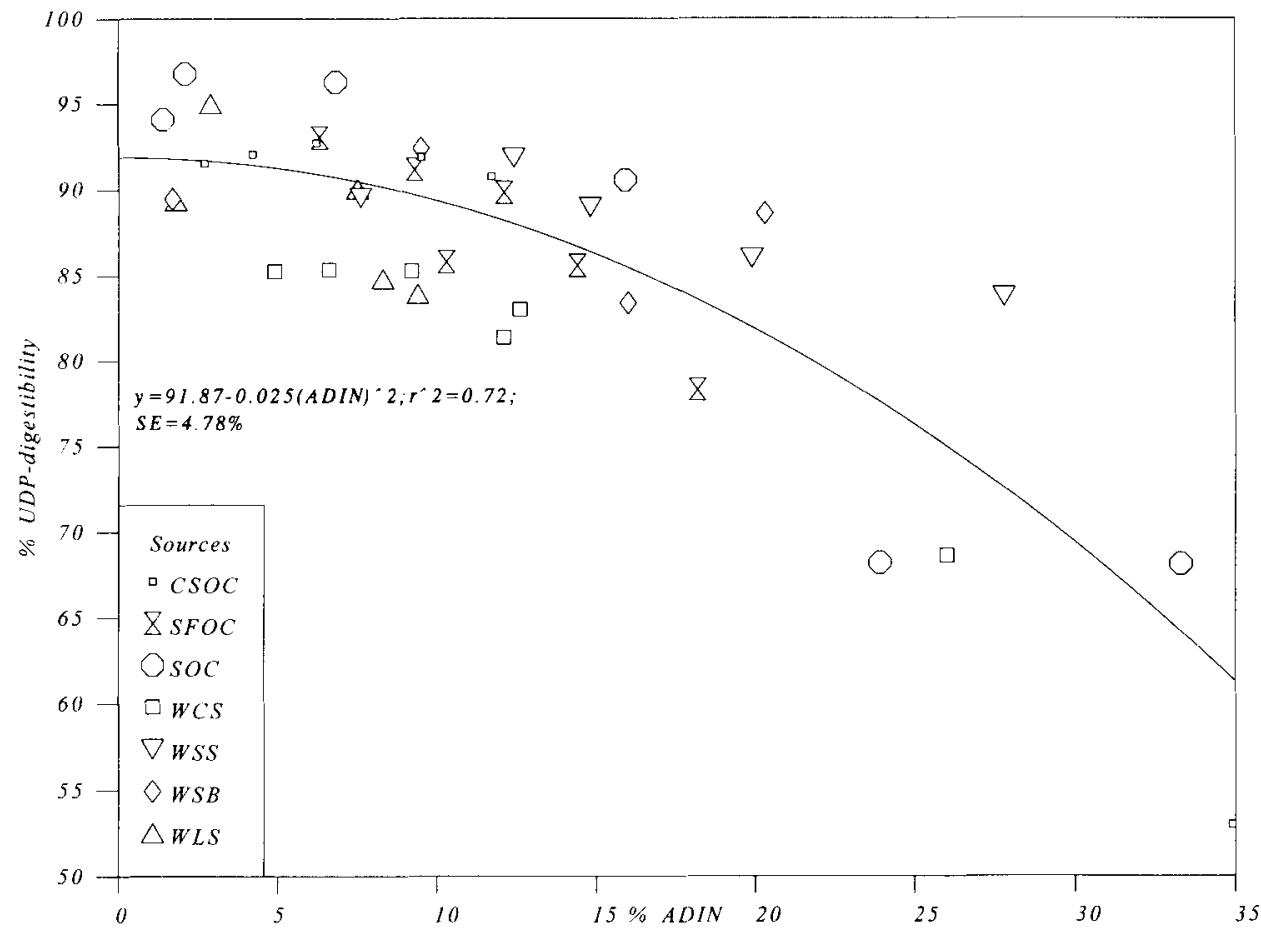

Figure 1 Relationship between acid detergent insoluble nitrogen (ADIN) as a percentage of total N and UDP-digestibility of various heat processed plant protein sources.

Table 2 UDP-D prediction equations for the individual protein sources

\begin{tabular}{lllcc}
\hline Source & $n$ & Prediction equation & $r^{2}$ & $p$ \\
\hline SFOC & 7 & UDP-D $(\%)=95.2-0.05(\mathrm{ADIN})^{2}$ & 0.89 & $p<0.01$ \\
CSOC & 6 & UDP-D $(\%)=90.4+0.61(\mathrm{ADIN})-0.05(\mathrm{ADIN})^{2}$ & 0.99 & $p<0.01$ \\
SOC & 6 & UDP-D $(\%)=95.2-0.029(\mathrm{ADIN})^{2}$ & 0.84 & $p<0.01$ \\
WSB & 4 & UDP-D $(\%)=90.9-0.20(\mathrm{ADIN})^{2}$ & 0.19 & $p<0.57$ \\
WSS & 5 & UDP-D $(\%)=48.8+5.02(\mathrm{ADIN})-0.14(\mathrm{ADIN})^{2}$ & 0.78 & $p<0.10$ \\
WCS & 6 & UDP-D $(\%)=86.5-0.026(\mathrm{ADIN})^{2}$ & 0.98 & $p<0.01$ \\
WLS & 5 & UDP-D $(\%)=92.9-0.09(\mathrm{ADIN})^{2}$ & 0.66 & $p<0.10$ \\
\hline
\end{tabular}

$\mathrm{SFOC}=$ sunflower oilcake meal $; \mathrm{CSOC}=$ cottonseed oilcake meal $; \mathrm{SOC}=$ soybean oilcake meal; $\mathrm{WSB}=$ whole soybeans; $\mathrm{SS}=$ whole sunflowerseed; WCS $=$ whole cottonseed; WLS $=$ whole lupinseed; $\mathrm{ADIN}=\%$ acid detergent insoluble nitrogen as a \% of total $\mathrm{N}$, in DM

in ADIN resulted in large and significant decreases in UDP$\mathrm{D}$, clearly indicating the non-linear relationship.

This is in contrast to the results of Nakamura et al. (1994), who found a linear relationship $\left(r^{2}=0.66\right)$ between ADIN and true nitrogen digestibility, concluding that ADIN was a weak indicator of heat damage in non-forage protein sources which included corn dried distillers grain (CDG) and milo dried distillers grain (MDG). A possible explanation for the conclusion of Nakamura et al. (1994), is that ADIN in distillers by-products may be as high as $50 \%$ digestible, and ADIN therefore is a poor predictor of N-digestibility in dried distillers grain. Nakamura et al. (1994), however, reported a linear relationship ( $r^{2}=0.84$ ) between UDP-D and true nitrogen digestibility of the heat processed soybean oilcake, sunflower oilcake and cottonseed oilcake samples, which is in agreement with our study $\left(r^{2}=0.74\right)$ when using these three pro- cessed sources. In both our study and in that of Nakamura et al. (1994), a poor relationship $\left(r^{2}=0.53\right)$ existed when only the unprocessed protein sources were taken into account. In their study only one heat treatment $\left(150^{\circ} \mathrm{C}\right.$ for $\left.90 \mathrm{~min}\right)$ was used with added xylose to induce severe heat damage. This resulted in abnormally high ADIN values, whereas in our study a broader range of ADIN values resulted from the factorial temperature $\times$ time interval arrangement. It can be concluded that ADIN is a useful indicator of UDP-D for selected heat processed and unprocessed plant proteins namely sunflower, cottonseed and soybean oilcakes as well as whole soybean, whole sunflowerseed, whole cottonseed and whole lupinseed. Dairy producers can help assure quality products by insisting that such test information be supplied with the purchase of heat processed products.

\section{Acknowledgements}

The authors wish to thank Dagmar Paulsmeier for her help with the statistical analysis, the personnel of the analytical laboratory for the chemical analysis, Abraham Makinta, Joseph Sehodi, Dawid Tshwale and Thomas Langa for taking care of the experimental animals and Hettie Olivier for the preparation of this manuscript.

\section{References}

A.O.A.C. 1984. Official Methods of analysis. Association of Official Analytical Chemists. (14th edn.) Washington, D.C.

BOILA, R.J. \& INGALLS, J.R. 1994. The ruminal degradation of dry matter, nitrogen and amino acids in wheat-based distillers' dried grains in sacco. Anim. Feed Sci. Technol. 48, 57.

BRODERICK, G.A., YANG, J.H. \& KOEGEL, R.G. 1993. Effect of steam heating alfalfa hay on utilization by lactating dairy cows. J. Dairy Sci. 76:165.

DE BOER, G., MURPHY, J.J. \& KENNELLY, J.J. 1987. Mobile 
nylon bag for estimating intestinal availability of rumen undegradable protein. J. Dairy Sci. 70:977.

DEMJANEC, B., MERCHEN, N.R., CREMIN, Jr., J.D., ALDRICH, C.G. \& BERGER, L.L. 1995. Effect of roasting on site and extent of digestion of soybean meal by sheep. 1. Digestion of nitrogen and amino acids. J. Anim. Sci. 73: 824.

DRACKLEY, J.K. \& SCHINGOETHE, D.J. 1986. Extruded blend of soybean meal and sunflower seeds for dairy cattle in early lactation. J. Dairy Sci. 69: 371.

FALDET, M.A., VOSS, V.L., BRODERICK, G.A. \& SATTER, L.D. 1991. Chemical, in vitro, and in situ evaluation of heattreated soybean proteins. J. Dairy Sci. 74: 2548.

FALDET, M.A., SATTER, L.D. \& BRODERICK, G.A. 1992. Determining optimal heat treatment of soybeans by measuring available lysine chemically and biologically with rats to maximize protein utilization by ruminants. J. Nutr. 122:151.

GOERING, H.K. \& VAN SOEST, P.J. 1970. Forage fiber analyses. Agric. Handbook No. 379. ARS - USDA, Washington, DC.

HUSSEIN, H.S., DEMJANEC, B., MERCHEN, N.R. \& ALDRICH, C.G. 1995. Effect of roasting on site and extent of digestion of soybean meal by sheep: II. Digestion of artifacts of heating. $J$. Anim. Sci. 73:835.

HVELPLUND, T., HOVELL, F.D. DeB., ØRSKOV, E.R. \& KYLE, D.J. 1994. True intestinal digestibility of protein estimated with sheep on intragastric infusion and with the mobile bag technique. Proceedings of the Society of Nutrition Physiology, VIII International Symposium on Ruminant Physiology, 25-30 September, Willingen, Germany, p. 64.

KIRKPATRICK, B.K. \& KENNELLY, J.J. 1985. The mobile nylon bag technique as a predictor of the nutritive value of feedstuffs for dairy cattle. 64th Annual Feeders' Day Report. Dept. Anim. Sci., Univ. of Alberta, Edmonton, Canada, p. 12.

MERCHEN, N.R. 1990. Effects of heat damage on protein digestion by ruminants: Alternative interpretations. Proceedings of Distillers Feed Conference, April 5, Syracuse, New York. pp. 57.
NAKAMURA, T., KLOPFENSTEIN, T.J. \& BRITTON, R.A. 1994. Evaluation of acid detergent insoluble nitrogen as an indicate of protein quality in nonforage proteins. J. Anim. Sci., 72, 1043.

NALSEN, T., OWENS, F.N., BUSH, L.J. \& ANZOLA, H. 1987. Animal Science Research Report. Oklahoma Agric. Exp. Sta., Oklahoma State University and USDA-Sci. Educ. Admin. Agric. Res., Washington. DC, p 153.

PENA, F., TAGARI, H. \& SATTER, L.D. 1986. The effect of heat treatment of whole cottonseed on site and extent of protein digestion in dairy cows. J. Anim. Sci., 62:1423.

REDDY, P.V., MORRILL, J.L. \& BATES, L.S. 1993. Effect of roasting temperatures on soybean utilization by young dairy calves. J. Dairy Sci., 76:1382.

SAS, 1990. SAS Users' Guide (6th edn.). Statistical Analysis System.

SATTER, L.D., DHIMAN, T.R. \& HSU, J.T. 1994. Use of heat processed soybeans in dairy rations. Proceedings of the Cornell Nutrition Conference for Feed Manufacturers, 18-20. October, Rochester, USA, p. 19.

SCHROEDER, G.E., ERASMUS, L.J. \& MEISSNER, H.H. 1996. Chemical and protein quality parameters of processed sunflower oilcake meal for use in dairy cattle diets. Anim. Feed Sci. Technol. $58,249$.

VAN SOEST, P.J.\& MASON, V.C. 1991. The influence of the Maillard reaction upon the nutritive value of fibrous feeds. Anim. Feed. Sci. Technol. 32, 45.

YANG, J.H., BRODERICK, G.A. \& KOEGEL, R.G. 1993. Effect of heat treating alfalfa hay on chemical composition and ruminal in vitro protein degradation. J. Dairy Sci. 76, 154.

YU, Y. 1976. Relationship between measurements of heating and acid-detergent insoluble nitrogen in heat damaged fresh alfalfa, haylage, and hay. J. Dairy Sci. 59, 1845.

YU, Y. 1977. Effect of heating of forages on quantitative changes of acid-detergent insoluble nitrogen. J. Dairy Sci. 60, 1813. 